\title{
ACORDO DE NÃO-PERSECUÇÃO PENAL: CONSTITUCIONALIDADE DO NEGOCIAL NO PROCESSO PENAL
}

CRIMINAL NON-PERSECUTION AGREEMENT: CONSTITUTIONALITY OF THE NEGOTIAL PROCEDURE IN THE CRIMINAL PROCEEDINGS

Andréa Walmsley Soares Carneiro ${ }^{1}$

FADIC

\section{Resumo}

O artigo objetiva investigar o acordo de não-persecução penal em função de três vertentes primordiais, nomeadamente os altos custos financeiros de um processo criminal, a possibilidade de reparação do dano e valorização do papel da vítima no processo penal.

Palavras-Chave

Processo penal. Acordo. Caso penal

\section{Abstract}

The article aims to investigate the non-prosecution agreement according to three main aspects, namely the high financial costs of a criminal case, the possibility of reparation of the damage and appreciation of the role of the victim in the criminal case.

Keywords

Criminal procedure. Agreement. Criminal case

O acordo de não-persecução penal surgiu na ordem jurídica pátria pelas previsões insertas na Resolução 181/2017² do Conselho

${ }^{1}$ Professora do Programa de Pós-Graduação da Faculdade Damas da Instrução Cristã. Procuradora da República.

2 Disponível em https://www.cnmp.mp.br/portal/images/Resolucoes/Resolução181.pdf. Acesso em 25/09/2019. 
DELICTAE, Vol. 4, No7, Jul..-Dez. $2019 \mid 24$

Nacional de Justiça, posteriormente modificada pela Resolução 183/2018 também do CNMP4.

${ }^{3}$ Disponível em https://www.cnmp.mp.br/portal/atos-e-normas/norma/5586/. Acesso em 25/09/2019/

${ }^{4}$ Art. 18. Não sendo o caso de arquivamento, o Ministério Público poderá propor ao investigado acordo de não persecução penal quando, cominada pena mínima inferior a 4 (quatro) anos e o crime não for cometido com violência ou grave ameaça a pessoa, o investigado tiver confessado formal e circunstanciadamente a sua prática, mediante as seguintes condições, ajustadas cumulativa ou alternativamente: (Redação dada pela Resolução n 183 , de 24 de janeiro de 2018)

I - reparar o dano ou restituir a coisa à vítima, salvo impossibilidade de fazê-lo; (Redação dada pela Resolução n 183 , de 24 de janeiro de 2018)

II - renunciar voluntariamente a bens e direitos, indicados pelo Ministério Público como instrumentos, produto ou proveito do crime; (Redação dada pela Resolução $n^{\circ}$ 183, de24 de janeiro de 2018)

III - prestar serviço à comunidade ou a entidades públicas por período correspondente à pena mínima cominada ao delito, diminuída de um a dois terços, em local a ser indicado pelo Ministério Público; (Redação dada pela Resolução nº 183, de 24 de janeiro de 2018)

IV - pagar prestação pecuniária, a ser estipulada nos termos do art. 45 do Código Penal, a entidade pública ou de interesse social a ser indicada pelo Ministério Público, devendo a prestação ser destinada preferencialmente àquelas entidades que tenham como função proteger bens jurídicos iguais ou semelhantes aos aparentemente lesados pelo delito; (Redação dada pela Resolução n 183 , de 24 de janeiro de 2018)

V - cumprir outra condição estipulada pelo Ministério Público, desde que proporcional e compatível com a infração penal aparentemente praticada. (Redação dada pela Resolução $\mathrm{n}^{\circ} 183$, de 24 de janeiro de 2018)

$\int 1^{\circ}$ Não se admitirá a proposta nos casos em que: (Redação dada pela Resolução n ${ }^{\circ} 183$, de 24 de janeiro de 2018)

I - for cabível a transação penal, nos termos da lei; (Redação dada pela Resolução n 183 , de 24 de janeiro de 2018)

II - o dano causado for superior a vinte salários mínimos ou a parâmetro econômico diverso definido pelo respectivo órgão de revisão, nos termos da regulamentação local;(Redação dada pela Resolução n ${ }^{\circ} 183$, de 24 de janeiro de 2018)

III - o investigado incorra em alguma das hipóteses previstas no art. 76, $\int 2^{\circ}$, da Lei $\mathrm{n}^{\circ}$ 9.099/95; (Redação dada pela Resolução n 183, de 24 de janeiro de 2018) 
DELiCTAE, Vol. 4, No7, Jul..-Dez. $2019 \mid 25$

IV - o aguardo para o cumprimento do acordo possa acarretar a prescrição da pretensão punitiva estatal; (Redação dada pela Resolução n ${ }^{\circ} 183$, de 24 de janeiro de 2018) $\mathrm{V}-\mathrm{o}$ delito for hediondo ou equiparado e nos casos de incidência da Lei $\mathrm{n}^{\circ} 11.340$, de 7 de agosto de 2006; (Redação dada pela Resolução nº 183, de 24 de janeiro de 2018) VI - a celebração do acordo não atender ao que seja necessário e suficiente para a reprovação e prevenção do crime. (Redação dada pela Resolução n 183 , de 24 de janeiro de2018)

$\llbracket 2^{\circ}$ A confissão detalhada dos fatos e as tratativas do acordo serão registrados pelos meios ou recursos de gravação audiovisual, destinados a obter maior fidelidade das informações, e o investigado deve estar sempre acompanhado de seu defensor. (Redação dada pela Resolução $n^{\circ} 183$, de 24 de janeiro de 2018)

$\int 3^{\circ} \mathrm{O}$ acordo será formalizado nos autos, com a qualificação completa do investigado e estipulará de modo claro as suas condições, eventuais valores a serem restituídos e as datas para cumprimento, e será firmado pelo membro do Ministério Público, pelo investigado e seu defensor. (Redação dada pela Resolução nº 183, de 24 de janeiro de2018)

$\int 4^{\circ}$ Realizado o acordo, a vítima será comunicada por qualquer meio idôneo, e os autos serão submetidos à apreciação judicial. (Redação dada pela Resolução $n^{\circ} 183$, de 24 de janeiro de 2018)

$\int 5^{\circ}$ Se o juiz considerar o acordo cabível e as condições adequadas e suficientes, devolverá os autos ao Ministério Público para sua implementação. (Redação dada pela Resolução $n^{\circ}$ 183 , de 24 de janeiro de 2018)

$\int 6^{\circ}$ Se o juiz considerar incabível o acordo, bem como inadequadas ou insuficientes as condições celebradas, fará remessa dos autos ao procurador-geral ou órgão superior interno responsável por sua apreciação, nos termos da legislação vigente, que poderá adotar as seguintes providências: (Redação dada pela Resolução n ${ }^{\circ} 183$, de 24 de janeiro de 2018) I - oferecer denúncia ou designar outro membro para oferecê-la; (Redação dada pela Resolução $n^{\circ} 183$, de 24 de janeiro de 2018)

II - complementar as investigações ou designar outro membro para complementála;(Redação dada pela Resolução n 183 , de 24 de janeiro de 2018)

III - reformular a proposta de acordo de não persecução, para apreciação do investigado; (Redação dada pela Resolução n 183 , de 24 de janeiro de 2018)IV - manter o acordo de não persecução, que vinculará toda a Instituição. (Redação dada pela Resolução $\mathrm{n}^{\circ} 183$, de 24 de janeiro de 2018)

$\int 7^{\circ} \mathrm{O}$ acordo de não persecução poderá ser celebrado na mesma oportunidade da audiência de custódia. (Redação dada pela Resolução n 183, de 24 de janeiro de 2018) 
Também prevê o acordo de não-persecução penal o "Projeto de Lei Anticrime", do atual Ministro da Justiça, com proposta de alteração de quatorze leis federais, inclusive o Código de Processo Penal, com a introdução do art. 28-A, que diminui a possibilidade de uso da referida avença processual pois a restringe aos casos de infração penal, sem violência ou grave ameaça, e com pena máxima inferior a quatro anos ${ }^{5}$.

$\int 8^{\circ}$ É dever do investigado comunicar ao Ministério Público eventual mudança de endereço, número de telefone ou e-mail, e comprovar mensalmente o cumprimento das condições, independentemente de notificação ou aviso prévio, devendo ele, quando for o caso, por iniciativa própria, apresentar imediatamente e de forma documentada eventual justificativa para o não cumprimento do acordo. (Redação dada pela Resolução $\mathrm{n}^{\circ} 183$, de 24de janeiro de 2018)

$\int 9^{\circ}$ Descumpridas quaisquer das condições estipuladas no acordo ou não observados os deveres do parágrafo anterior, no prazo e nas condições estabelecidas, o membro do Ministério Público deverá, se for o caso, imediatamente oferecer denúncia. (Incluído pela Resolução n 183 , de 24 de janeiro de 2018)

$\int 10 \mathrm{O}$ descumprimento do acordo de não persecução pelo investigado também poderá ser utilizado pelo membro do Ministério Público como justificativa para o eventual não oferecimento de suspensão condicional do processo. (Incluído pela Resolução n 183, de24 de janeiro de 2018)

\11 Cumprido integralmente o acordo, o Ministério Público promoverá o arquivamento da investigação, nos termos desta Resolução. (Incluído pela Resolução n 183, de 24 de janeiro de 2018)

\12 As disposições deste Capítulo não se aplicam aos delitos cometidos por militares que afetem a hierarquia e a disciplina. (Incluído pela Resolução n 183, de 24 de janeiro de 2018)

\13 Para aferição da pena mínima cominada ao delito, a que se refere o caput, serão consideradas as causas de aumento e diminuição aplicáveis ao caso concreto. (Incluído pela Resolução $\mathrm{n}^{\circ} 183$, de 24 de janeiro de 2018)

5 Art. 28-A. Não sendo o caso de arquivamento e tendo o investigado confessado circunstanciadamente a prática de infração penal, sem violência ou grave ameaça, e com pena máxima inferior a quatro anos, o Ministério Público poderá propor acordo de não persecução penal, desde que necessário e suficiente para a reprovação e prevenção do crime, mediante as seguintes condições, ajustadas cumulativa ou alternativamente: I - reparar o dano ou restituir a coisa à vítima, salvo impossibilidade de fazê-lo; 
II - renunciar voluntariamente a bens e direitos, indicados pelo Ministério Público como instrumentos, produto ou proveito do crime;

III - prestar serviço à comunidade ou a entidades públicas por período correspondente à pena mínima cominada ao delito, diminuída de um a dois terços, em local a ser indicado pelo Ministério Público;

IV - pagar prestação pecuniária, a ser estipulada nos termos do art. 45 do Código Penal, a entidade pública ou de interesse social a ser indicada pelo Ministério Público, devendo a prestação ser destinada preferencialmente àquelas entidades que tenham como função proteger bens jurídicos iguais ou semelhantes aos aparentemente lesados pelo delito; e V - cumprir, por prazo determinado, outra condição indicada pelo Ministério Público, desde que proporcional e compatível com a infração penal imputada.

$\int 1^{\circ}$ Para aferição da pena mínima cominada ao delito, a que se refere o caput, serão consideradas as causas de aumento e diminuição aplicáveis ao caso concreto.

$\int 2^{\circ}$ Não será admitida a proposta nos casos em que:

I - for cabível transação penal de competência dos Juizados Especiais Criminais, nos termos da lei;

II - for o investigado reincidente ou se houver elementos probatórios que indiquem conduta criminal habitual, reiterada ou profissional, salvo se insignificantes as infrações penais pretéritas;

III - ter sido o agente beneficiado anteriormente, no prazo de cinco anos, em acordo de não persecução penal, transação penal ou suspensão condicional do processo; e

IV - não indicarem os antecedentes, a conduta social e a personalidade do agente, bem como os motivos e as circunstâncias, ser necessária e suficiente a adoção da medida.

$\int 3^{\circ} \mathrm{O}$ acordo será formalizado por escrito e será firmado pelo membro do Ministério Público, pelo investigado e seu defensor.

$\int 4^{\circ}$ Para homologação do acordo, será realizada audiência na qual o juiz deverá verificar a sua legalidade e voluntariedade, devendo, para este fim, ouvir o investigado na presença do seu defensor.

$\int 5^{\circ}$ Se o juiz considerar inadequadas ou insuficientes as condições celebradas, devolverá os autos ao Ministério Público para reformular a proposta de acordo de não persecução, com concordância do investigado e seu defensor.

$\int 6^{\circ}$ Homologado judicialmente o acordo de não persecução penal, o juiz devolverá os autos ao Ministério Público para que inicie sua execução perante o juízo de execução penal. $\int 7^{\circ} \mathrm{O}$ juiz poderá recusar homologação à proposta que não atender aos requisitos legais ou quando não for realizada a adequação, prevista no $\ 5^{\circ}$. 
Diga-se que as referidas resoluções do Conselho Nacional do Ministério Público suscitaram uma série de questionamentos aos operadores do direito. Destaque-se ainda que a Resoluções CNMP 181/2017 e 183/2018 tiveram suas constitucionalidades questionadas por meio da ADIN proposta pela AMB, cuja petição inicial foi aditada quando do advento da segunda resolução, e com mérito ainda não apreciado pelo Supremo Tribunal Federal ${ }^{6}$.

$\int 8^{\circ}$ Recusada a homologação, o juiz fará remessa dos autos ao Ministério Público para análise da necessidade de complementação das investigações ou oferecimento de denúncia. $\int 9^{\circ}$ A vítima será intimada da homologação do acordo.

$\int 10$. Descumpridas quaisquer das condições estipuladas no acordo, o Ministério Público deverá comunicar o juízo, para fins de sua rescisão e posterior oferecimento de denúncia. $\int 11$. O descumprimento do acordo de não persecução pelo investigado também poderá ser utilizado pelo membro do Ministério Público como justificativa para o eventual não oferecimento de suspensão condicional do processo.

\12. A celebração e o cumprimento do acordo tratado neste artigo não constará de certidão de antecedentes criminais, salvo para os fins previstos no inciso III do $\$ 2^{\circ}$.

$\int$ 13. Cumprido integralmente o acordo, o juízo competente decretará a extinção de punibilidade.

$\int 14$. Não corre a prescrição durante a vigência de acordo de não-persecução. (NR)

6 A AMB apresentou, nesta sexta-feira (15), pedido de aditamento à Ação Direta de Inconstitucionalidade (ADI) 5790/DF, de relatoria do ministro do Supremo Tribunal Federal (STF) Ricardo Lewandowski, devido à revogação parcial da Resolução n 181/2017 do Conselho Nacional do Ministério Público (CNMP), que dispõe sobre instauração e tramitação do procedimento investigatório criminal a cargo do Ministério Público. A alteração da Resolução foi aprovada por unanimidade pelo Plenário do Conselho durante a $23^{\circ}$ Sessão Ordinária, nessa terça-feira (12).

A entidade requereu ao STF que examine e julgue as inconstitucionalidades que permaneceram, a exemplo do artigo 18, pelo fato de terem sido criadas hipóteses de acordo de não-persecução penal que não estão previstas em lei. A Associação ressalta que "como a decisão tomada pelo CNMP não acrescentou nova regra que mereça ser impugnada, mas apenas regras que prejudicaram em parte a presente ação direta de inconstitucionalidade, bastará considerar a perda parcial de objeto da ação e o prosseguimento quanto a inconstitucionalidade subsistente".

Argumento 
Feitas estas considerações preliminares, a pergunta que se impõe é a seguinte: é constitucional a previsão de um acordo de nãopersecução penal em uma Resolução do Conselho Nacional do Ministério Público? As previsões constantes dos artigos $5 .^{\circ}, \mathrm{LIV}^{7}$ e $22, \mathrm{I} \mathrm{II}^{8} \mathrm{da}$ Constituição Federal impedem, sob pecha de inconstitucionalidade, o regramento do acordo de não-persecução penal por meio de uma espécie normativa infralegal?

As respostas a ambas as questões demandam o enfretamento de uma série de questões de direito penal e processual penal ${ }^{9}$, no contexto de uma sociedade complexa e ávida por respostas rápidas e eficientes às questões atinentes à criminalidade.

Para a Associação, é preocupante a manutenção dessas hipóteses de acordo de nãopersecução penal no art. 18, "Porque a despeito de agora haver a submissão ao Poder Judiciário do acordo firmado, é inegável que diante da inexistência de lei dispondo sobre ela, resultará uma insegurança jurídica sem tamanho, diante da possibilidade de magistrados recusarem ou aceitarem esses acordos, com base exclusivamente no fato de a Resolução não poder dispor sobre a matéria sem prévia previsão legal", argumenta, em trecho da ação. Disponível em http://www.amb.com.br/aditamento-adi5790/?doing_wp_cron=1551740634.2159020900726318359375. Acesso em 04/03/2019.

${ }^{7}$ Art. $5^{\circ}$ Todos são iguais perante a lei, sem distinção de qualquer natureza, garantindo-se aos brasileiros e aos estrangeiros residentes no País a inviolabilidade do direito à vida, à liberdade, à igualdade, à segurança e à propriedade, nos termos seguintes:

LIV - ninguém será privado da liberdade ou de seus bens sem o devido processo legal; 8 Art. 22. Compete privativamente à União legislar sobre:

I - direito civil, comercial, penal, processual, eleitoral, agrário, marítimo, aeronáutico, espacial e do trabalho;

${ }^{9}$ Como assevera Paulo Queiroz: “(...) o processo penal é um continum do direito penal, ou seja, é o próprio direito penal em ação, em movimento, razão pela qual formam uma unidade, um todo indissolúvel. Afinal, não há direito penal sem processo penal, nem processo penal sem direito penal, pois estão logicamente implicados. O processo é, pois, o motor que põe em funcionamento o sistema penal. Não, por acaso, ele é o mais sensível às mudanças e reformas políticas, marcadas por avanços e retrocessos".

QUEIROZ,

Paulo. Direito processual penal: por um sistema integrado de direito, processo e execução penal. Salvador: Editora Juspodivm, 2018, p. 29. 
Não se descura que o Supremo Tribunal Federal, quando do julgamento da Ação Declaratória de Constitucionalidade n. ${ }^{\circ} 12$, reconheceu o caráter normativo primário às resoluções do Conselho Nacional de Justiça $^{10}$, o que se aplicaria, também, analogicamente, ao Conselho Nacional do Ministério Público ${ }^{11}$, diante da paridade de estatura e conformação constitucional dos referidos conselhos.

Parece claro que algumas medidas de simplificação do sistema processual penal escancaram exigências de ordem prática indiscutíveis. De fato, os órgãos de persecução penal se ressentem, de forma geral, das agruras inerentes à grande demanda criminal e, lado outro, dos cada vez mais escassos recursos públicos destinados a satisfazer as suas funções próprias.

Se, de um lado, o Estado absorveu o monopólio do exercício da força legítima para a punição da conduta tida por criminosa ${ }^{12}$,

http:/ / redir.stf.jus.br/paginadorpub/paginador.jsp?docTP=AC\&docID=606840. Acesso em 51/09/2019.

${ }^{11}$ Dispõe o art. 130-A da Constituição Federal, verbis:

Art. 130-A. O Conselho Nacional do Ministério Público compõe-se de quatorze membros nomeados pelo Presidente da República, depois de aprovada a escolha pela maioria absoluta do Senado Federal, para um mandato de dois anos, admitida uma recondução, sendo: (Incluído pela Emenda Constitucional no 45, de 2004)

(...)

$\int 2^{\circ}$ Compete ao Conselho Nacional do Ministério Público o controle da atuação administrativa e financeira do Ministério Público e do cumprimento dos deveres funcionais de seus membros, cabendo lhe:

I zelar pela autonomia funcional e administrativa do Ministério Público, podendo expedir atos regulamentares, no âmbito de sua competência, ou recomendar providências; (...)".

12 Segundo Cláudio Brandão, "Deve-se salientar que outrora o Direito Penal já foi considerado como instrumento do arbítrio estatal, mas, quando esse ramo do ordenamento jurídico se voltou para a tutela dos referidos bens jurídicos, ele rompeu com seu passado nebuloso e passou a figurar como um Direito garantidor do homem, de sua liberdade e da sociedade”. BRANDÃO, Cláudio. Teoria Jurídica do Crime. Coleção: Ciência Criminal 
DELiCTAE, Vol. 4, No7, Jul..-Dez. $2019 \mid 31$

por outro lhe carreou o ônus de garantir uma resposta eficiente às exigências sociais de prevenção, repressão e ressocialização. Ocorre que de há muito se percebeu que dita tarefa parece inesgotável e os recursos públicos são limitados e esgotáveis por natureza.

A ideia da justiça processual penal negocial não é novidade no cenário brasileiro. Basta ver que a própria lei 9.099/95 trouxe, em seus artigos 76 e 89, respectivamente, os institutos da transação penal e da suspensão condicional do processo, de constitucionalidade reconhecida pelo Supremo Tribunal Federal ${ }^{13}$.

Contemporânea, vol. 1. Coord: Cláudio Brandão. Belo Horizonte: Editora D’Plácido, 2019, p. 39.

${ }^{13}$ Neste sentido, a ementa que segue, verbis: EMENTA Habeas corpus. Penal. Condenação pelos crimes de lesão corporal (CP, art. 129) e desacato (CP, art. 331). Dosimetria de pena. Fixação da pena-base do crime de desacato acima do mínimo legal. Fundamentação idônea. Alegado bis in idem. Não ocorrência. Suspensão condicional do processo (art. 89 da Lei n ${ }^{\circ}$ 9.099/95). Não cabimento. Fundamentada recusa do Ministério Público em propor o benefício. Aceitação da recusa pela autoridade judicial. Possibilidade. Precedentes. Natureza de transação processual da suspensão condicional do processo. Inexistência de direito público subjetivo à aplicação do art. 89 da Lei 9.099/95. Precedentes. Constrangimento ilegal não evidenciado. Ordem denegada. 1. A jurisprudência da Corte preconiza que a via estreita do habeas corpus não permite que se proceda à ponderação ou ao reexame das circunstâncias judiciais referidas no art. 59 do Código Penal consideradas na sentença condenatória $\left(\mathrm{HC}^{\circ}{ }^{\circ} 100.371 / \mathrm{CE}\right.$, Primeira Turma, Relator o Ministro Ricardo Lewandowski, DJe de 21/5/10; HC no 121.569/SP, Primeira Turma, de minha relatoria, DJe 16/5/14). 2. Todavia, em matéria de dosimetria de pena, cabe ao Supremo Tribunal Federal exercer o controle da legalidade e da constitucionalidade dos critérios empregados, bem como a correção de eventuais discrepâncias, se gritantes ou arbitrárias ( $\mathrm{HC} \mathrm{n}^{\circ}$ 120.095/MS, Primeira Turma, Relatora a Ministra Rosa Weber, DJe 20/5/14). 3. O acórdão proferido pelo Tribunal Regional majorou a pena-base do paciente pelo delito de desacato de forma fundamentada, considerando como consequências do crime os prejuízos psicológicos causados à vítima, devidamente comprovados, não incidindo, portanto, no apontado bis in idem, uma vez que o fato não é elemento normativo do tipo penal do art. 331 do Código Penal, que é a dignidade da Administração Pública, imprescindível para o desempenho regular da atividade administrativa (CAPEZ, Fernando e PRADO, Stela. 
Mais especificamente a transação penal (art. 76 da lei 9.099/95) representa um golpe mortal na antiquada ideia do princípio da obrigatoriedade da ação penal, entendido tradicionalmente como a obrigação do órgão ministerial, se não for caso de arquivamento ou novas diligências indispensáveis à formulação da opinio delicti, oferecer acusação

Código Penal comentado. 3. ed. São Paulo: Saraiva, 2012, p. 662). 4. Nesse aspecto, o acórdão proferido por aquele Tribunal Regional não apresenta mácula, uma vez que circunstância elementar do tipo incriminador em questão não foi sopesada para majorar a pena-base. 5. Quanto à pretendida concessão da suspensão condicional do processo (art. 89 da Lei no 9.099/95), anoto que a jurisprudência da Corte já decidiu que o benefício não é cabível se o Ministério Público, de forma devidamente fundamentada, como no caso, deixa de propô-la e o Juiz concorda com a recusa (HC no 89.842/SP, Primeira Turma, Relator o Ministro Sepúlveda Pertence, DJ 15/9/06). Desse entendimento, não dissentiu o aresto ora questionado. 6. É pertinente se destacar que a suspensão condicional do processo tem natureza de transação processual, não existindo, portanto, direito público subjetivo do paciente à aplicação do art. 89 da Lei 9.099/95 (HC no 83.458BA, Primeira Turma, Relator o Ministro Joaquim Barbosa, DJ de 6/2/03; HC n ${ }^{\circ}$ 101.369/SP, Primeira Turma, de minha relatoria, DJe de 28/11/11). 7. Ordem denegada. (HC 129346 / ES ESPÍRITO SANTO HABEAS CORPUS Relator(a): Min. DIAS TOFFOLI Julgamento: 05/04/2016 Órgão Julgador: Segunda Turma). Disponível em http://stf.jus.br/portal/jurisprudencia/listarJurisprudencia.asp?s1=\%28TRANSACAO+ PENAL+E+CONSTITUCIONALIDADE\%29\&base=baseAcordaos\&url=http: $/ /$ tinyu rl.com/yyb2kvlf. Acesso em 21/09/2109. 
formal em juízo ${ }^{14}$ em face do sujeito sobre o qual recaem indícios suficientes de autoria de um crime cuja materialidade restou comprovada ${ }^{15}$.

Ocorre que o multicitado art. 76 dispõe expressamente que, nas hipóteses de ação penal pública incondicionada ou na pública condicionada, presente a condição de procedibilidade da representação, "O Ministério Público poderá propor a aplicação imediata de pena restritiva de direitos ou multas, a ser especificada na proposta".

Tem-se de maneira clara que, uma situação que outrora demandava o oferecimento de uma peça acusatória inicial pelo Parquet, por obrigação legal, inclusive sob pena de responsabilização do membro ministerial, passou, após a edição do referido diploma legislativo, a suscitar solução simplificada e desburocratizada, com imediata aplicação de penas não privativas de liberdade, negociadas pelas partes e submetidas ao crivo do Poder Judiciário.

14 Afirmam Távora e Alencar: “Não se pode olvidar (...) que a Lei n 9.099/95, objetivando mitigar a sanha penalizadora do Estado, instituiu uma contemporização ao princípio da obrigatoriedade, que ganhou o nome de princípio da obrigatoriedade mitigada ou discricionariedade regrada, que nada mais é que, nas infrações de menor potencial ofensivo, a possibilidade, com base no art. 76 da Lei dos Juizados, da oferta de transação penal, é dizer, a submissão do suposto autor da infração a uma medida alternativa, não privativa de liberdade, evitando-se a oferta da denúncia. Substitui-se o embate formal em juízo, pela composição entre as partes". TÁVORA, Nestor et ALENCAR, Rosmar Rodrigues. Curso de Direito Processual Penal. 7. ed. Salvador: Editora Juspodivm, 2012, p. 167.

${ }^{15}$ Justa causa para a ação penal, cuja ausência autoriza a rejeição da denúncia ou da queixa, na literalidade do art. 395, inciso III, do Código de Processo Penal (com redação conferida pela Lei $\mathrm{n}^{\circ} 11.719$, de 2008), verbis:

Art. 395. A denúncia ou queixa será rejeitada quando: (Redação dada pela Lei no 11.719 , de 2008).

I - for manifestamente inepta;- (Incluído pela Lei no 11.719, de 2008).

II - faltar pressuposto processual ou condição para o exercício da ação penal; ou (Incluído pela Lei no 11.719, de 2008).

III - faltar justa causa para o exercício da ação penal. (Incluído pela Lei no 11.719 , de 2008). Parágrafo único. (Revogado). (Incluído pela Lei no 11.719, de 2008). 
Assim, para as infrações penais de menor potencial ofensivo $^{16}$, afigura-se, ao menos em tese, cabível a transação penal, desde que preenchidos os requisitos legais.

Entretanto, tal solução não se estenderia para os crimes de médio potencial ofensivo por ausência de previsão legal, salvo admitida, como fazemos, a constitucionalidade das Resoluções CNMP 181/2017 e $183 / 2018$.

Ocorre que, em situações de infrações mais graves que as de menor potencial ofensivo, porém praticadas sem violência ou grave ameaça à pessoa, e notadamente com mais sentida repercussão patrimonial, repitase, passou-se na praxe forense a sentir a necessidade da utilização regrada de mecanismos de simplificação procedimental.

No âmbito do Ministério Público Federal, a orientação Conjunta n. 03/2018, das 2.a, 4.a e 5.a Câmara de Coordenação e Revisão, respeitada a independência funcional, quanto à realização de acordos de não persecução penal, disciplina:

1. Verificando não ser o caso de arquivamento de notícia de fato (NF), inquérito policial (IPL) ou procedimento investigatório criminal (PIC), o membro oficiante determinará que os autos sejam instruídos com os antecedentes criminais do investigado a fim de examinar a possibilidade de proposição de acordo de não persecução penal ${ }^{17}$.

${ }^{16}$ Dispõe o artigo 61 da Lei n. ${ }^{\circ} 9.099 / 95$, verbis:

Art. 61. Consideram-se infrações penais de menor potencial ofensivo, para os efeitos desta Lei, as contravenções penais e os crimes a que a lei comine pena máxima não superior a 2 (dois) anos, cumulada ou não com multa. (Redação dada pela Lei no 11.313, de 2006) 17 Disponível em http://www.mpf.mp.br/atuacaotematica/ccr2/orientacoes/documentos/orientacao-conjunta-no-3-2018-assinada-pgr006676712018.pdf. Acesso em 25/09/2019. 
De fato, os altos custos financeiros de um processo criminal, a possibilidade de reparação do dano e valorização do papel da vítima por meio de outros instrumentos apontam no sentido da necessidade imperiosa do acordo de não-persecução penal como solução legal, justa e razoável.

Há muito tempo os operadores do direito que laboram na justiça criminal já percebiam um vácuo de regramento legal que compelia o manejo de ações penais dispendiosas, demoradas e ainda a indemonstrável eficiência prática das penas para fins de resposta adequada ao crime ${ }^{18}$.

Aliás, a prática jurídica e as necessidades e dificuldades que se apresentam no cotidiano dos processos criminais acabam gerando soluções que são posteriormente incorporadas - ainda que com delineamentos distintos - pelas normas processuais.

A respeito do plea bargaining, assevera Almiro Velludo Salvador

Netto:

Em síntese, algo bastante interessante de ser notado no sistema anglo-saxão é o fato de o plea bargaining aparecer não apenas como um instituto jurídico em si mesmo, mas significar uma certa mentalidade para o oferecimento de respostas jurisdicionais aos problemas penais concretos. Essa dinâmica de acordos, aliás, não foi gestada primeiro intelectualmente para depois ser transferida à prática forense. Ao contrário, o que houve foi uma habitualidade judiciária que progressivamente ganhou importância, até atingir um excessivo, e agora criticado, protagonismo ${ }^{19}$.

${ }^{18}$ Afirma von Liszt: "Y, de existir esa rara fórmula de medida, bien vale la preocupación, que sobre los sillares de la antropologia y la sociologia, en aquel punto donde se cruzan las parábolas de la ética y del Derecho, ella sería la clave penal de ese arco de triunfo soñado esterilmente por la achacosa justicia en la eterna cruzada contra el crimen". Liszt, Franz von. Tratado de Derecho Penal. 1. ed. Florida: Valletta Ediciones, 2007, p. 619.

19 SALVADOR NETTO, Almiro Velludo. Plea bargaining e seus contornos jurídicos: desafios estrangeiros para o Brasil. Revista Brasileira de Ciência Criminais, vol. 155/2019, p. 229-264, maio/2019, p. 236. 
É certo que apenas exigências de ordens prática e utilitária não autorizam o emprego de um instituto como o acordo de não-persecução penal. Entretanto, o que se pretende afirmar, neste passo, é que o referido acordo não enfrenta a mancha da inconstitucionalidade ou da ilegalidade.

Em realidade, o acordo de não-persecução não é de matéria penal ou processual penal, mas trata de questão de natureza políticocriminal, a ser enfrentada pelo titular da ação penal pública, qual seja, o Ministério Público ${ }^{20}$.

Ora, "além de definir crimes e cominar penas, o direito penal dispõe sobre os princípios fundamentais que regulam a atividade penal do Estado e prevê os institutos indispensáveis ao exercício desse poder ${ }^{21}$ ". O referido acordo não define infrações, não prevê penas em abstrato, nem mesmo trata de institutos relacionados ao poder punitivo estatal. Daí não poder ser reconhecido como instituto de índole penal.

Por outro lado, também não é um instituto de índole processual, mas procedimental, regulamentado e inserido no bojo do procedimento investigatório criminal a cargo do Ministério Público, de modo a prescindir de lei em sentido formal para a sua disciplina.

Neste sentido:

Assim, considerando-se que o acordo de não persecução é extrajudicial (não envolve o exercício da ação penal), vez que realizado no âmbito de um procedimento administrativo investigatório, sem o prévio exercício de uma pretensão punitiva, é dizer, sem o prévio oferecimento da denúncia ou

${ }^{20}$ CABRAL, Rodrigo Leite Ferreira. Um panorama sobre o acordo de não persecução penal (art. 18 da Resolução181/17 do CNMP in Acordo de não persecução. Org: Rogério Saches Cunha, Francisco Dirceu Barros, Renee do Ó Souza, Rodrigo Leite Ferreira Cabral. Salvador: Editora Juspodivm, 2017, p. 30.

${ }^{21}$ QUEIROZ, Paulo. Direito processual penal: por um sistema integrado de direito, processo e execução penal. Salvador: Editora Juspodivm, 2018, p. 27. 
queixa, não há o menor sentido em atribuir-se à regulamentação desse acordo a natureza processual. $O$ acordo é um negócio jurídico extrajudicial, que não envolve o prévio oferecimento da denúncia, nem exige uma prestação jurisdicional do Estado-Juiz ${ }^{22}$.

Trata-se, em realidade, de um negócio jurídico ${ }^{23}$ obstativo da propositura da ação penal ou que meramente difere o momento de eventual oferecimento da peça pórtica acusatória e o subordina ao inadimplemento das condições anteriormente avençadas.

E a constitucionalidade do acordo de não-persecução foi assentada em sede jurisdicional, em decisão proferida no bojo do mandado de segurança 0804975-89.2019.4.05.00, da relatoria do Exmo. Desembargador Federal Paulo Roberto de Oliveira Lima, do Egrégio Tribunal Regional Federal da 5.a Região, cuja ementa, por sua clareza, importância e robusta fundamentação, abaixo se transcreve, verbis:

EMENTA. PENAL E PROCESSUAL PENAL. MANDADO DE SEGURANÇA. INVESTIGAÇÃO CRIMINAL PRESIDIDA PELO ÓRGÃO MINISTERIAL. ACORDO DE NÃO PERSECUÇÃO PENAL APRESENTADO PELO MINISTÉRIO PÚBLICO E NÃO APRECIADO PELO JULGADOR. RESOLUÇÃO No 181/2017, DO CNMP. HARMONIA

${ }^{22}$ CABRAL, Rodrigo Leite Ferreira. Um panorama sobre o acordo de não persecução penal (art. 18 da Resolução181/17 do CNMP in Acordo de não persecução. Org: Rogério Saches Cunha, Francisco Dirceu Barros, Renee do Ó Souza, Rodrigo Leite Ferreira Cabral. Salvador: Editora Juspodivm, 2017, p. 33

${ }^{23}$ Dispõe o Código Civil:

Art. 104. A validade do negócio jurídico requer:

I - agente capaz;

II - objeto lícito, possível, determinado ou determinável;

III - forma prescrita ou não defesa em lei. 
COM OS DITAMES DA JUSTIÇA PÁTRIA. AUSÊNCIA DE DECLARAÇÃO DE INCONSTITUCIONALIDADE PELO STF. PRESUNÇÃO DE LEGITIMIDADE. CONCESSÃO DA SEGURANÇA.

1. Mandado de segurança impetrado pelo MINISTÉRIO PÚBLICO FEDERAL contra ato do Juízo da $12^{\mathrm{a}}$ Vara da $\mathrm{SJ} / \mathrm{CE}$ que, em sede de procedimento investigatório, recusou-se a apreciar acordo de não persecução penal apresentado pelo Órgão Ministerial, ora impetrante, e declarou incidentalmente a inconstitucionalidade do art. 18, e incisos, da Resolução No 181/2017, do CNMP, que disciplina referido instituto;

2. Por força do acordo proposto, o investigado (na qualidade de único responsável por uma empresa de assessoria contábil e fiscal, confessou ter emitido atestado de capacidade técnica inidôneo, sendo tal documento utilizado por outra empresa num pregão eletrônico promovido, em 2016, pela Procuradoria da República do Estado do Ceará) comprometeu-se a pagar prestação pecuniária correspondente a 15 (quinze) cestas básicas e prestar serviços comunitários. Por seu turno, o MPF, cumpridas integralmente as referidas obrigações, promoveria $\mathrm{O}$ arquivamento da investigação;

3. A autoridade impetrada fundamentou seu decisum enfatizando que "a instituição por via de Resolução do Conselho Nacional do Ministério Público de exceção ao princípio da obrigatoriedade vai de encontro ao que diz a lei e a Constituição. Isso porque, a Constituição determina que o Ministério Público deve promover a ação, nos termos da lei, e a lei penal e processual penal não abrem margem de oportunidade para o Ministério Público deixar de promover a ação penal" e, ainda, que "o CNMP foi ativista para afastar a necessidade de lei em sentido estrito para regular essa questão (invadiu esfera do Poder Legislativo) e, também, lei para regular perante qual órgão devem ser cumpridas penas alternativas (invadiu esfera do Poder Legislativo e do próprio Poder Judiciário), de modo que não há base constitucional e legal para prosseguir com aplicação desse instituto"; 
4. Com a presente impetração, o MPF busca a concessão da segurança para suspender os efeitos da decisão que declarou inconstitucional a citada Resolução do CNMP e para que seja ordenado à autoridade impetrada a imediata apreciação do acordo efetuado nos autos, defendendo, em síntese: a) a viabilidade do presente mandado de segurança por tratar-se de decisão judicial contra a qual não cabe recurso com efeito suspensivo, nos termos do art. 5 , II, da Lei n ${ }^{\circ}$ 12.016/2009; b) que o acordo de não persecução penal "pretende dar maior racionalidade ao sistema penal brasileiro", "permite que o Ministério Público e o Poder Judiciário priorizem os delitos mais graves", além de possibilitar "uma resposta muito mais rápida aos crimes de pouca gravidade"; c) que o "STF já reconheceu que as resoluções do CNJ, e portanto, também, as do CNMP, ostentam 'caráter normativo primário' (STFADC $12 \mathrm{MC}$ ) e, desse modo, o CNJ e o CNMP, 'no exercício de suas atribuições administrativas' ostentam o poder de 'expedir atos regulamentares'. Esses, por sua vez, são atos de comando abstrato que dirigem aos seus destinatários comandos e obrigações, desde que inseridos na esfera de competência do órgão' (STF - MS 27621); d) que a regulamentação do aludido instituto (acordo de não persecução penal) não constitui invasão de competência legislativa da União para tratar de matéria processual (art. 22, inciso I, da CF), considerando que tal instituto está inserido no âmbito administrativo, mais especificamente no Procedimento Investigatório Criminal (PIC) do Ministério Público; e) que "o fato de existirem ADIs propostas, sem liminar concedida, só corrobora a vigência das Resoluções e, portanto, não poderiam servir como fundamento para a declaração de inconstitucionalidade da resolução, o que, desde logo, aponta para a inadequação da decisão combatida";

5. Cabível, na hipótese, o manejo da ação mandamental, uma vez que o ato impugnado ocorreu quando ainda não formada a relação processual, o que impossibilita o uso de correição parcial, nos moldes do disposto no art. 280, do Regimento Interno deste TRF/5; 
DeLICTAE, Vol. 4, No7, Jul..-Dez. $2019 \mid 40$

6. A Resolução $N^{\circ} 181 / 2017$, do CNMP e o acordo de não persecução penal são harmônicos com os ditames da justiça e da sociedade moderna, com o movimento que visa a descarcerização e, sobretudo, com os princípios da celeridade e da economia processual, constitucionalmente consagrados; 7. O acordo de não persecução penal não constitui matéria relativa ao direito processual penal, considerando que este incide em fase administrativa anterior à instauração do processo penal propriamente dito, inclusive evitando a instauração do próprio processo, de modo que, sua regulamentação por meio de Resolução do CNMP não pode caracterizar violação ao art. 22 , da $\mathrm{CF} / 88$;

8. Em face do (ainda) não julgamento das demandas que contestam a constitucionalidade da Resolução CNMP $\mathrm{n}^{\circ}$ 181/2017, presume-se sua legitimidade, impondo-se a concessão da ordem para assegurar seja apreciado o acordo de não persecução penal apresentado pelo Parquet perante o Juízo impetrado;

9. Concessão da segurança.

A questão em tela, malgrado suscite variegadas discussões, apresenta-se como reconhecimento expresso de que o desenvolvimento do direito penal, enquanto meio de regulação da vida em sociedade, e do processo penal, como seu instrumento de aplicação, demandam um exercício contínuo de reflexão e aprimoramento.

\section{REFERÊNCIAS}

BRANDÃO, Cláudio. Teoria Jurídica do Crime. Coleção: Ciência Criminal Contemporânea, vol. 1. Coord: Cláudio Brandão. Belo Horizonte: Editora D’Plácido, 2019. 
CABRAL, Rodrigo Leite Ferreira. Um panorama sobre o acordo de não persecução penal (art. 18 da Resolução181/17 do CNMP in Acordo de não persecução. Org: Rogério Saches Cunha, Francisco Dirceu Barros, Renee do Ó Souza, Rodrigo Leite Ferreira Cabral. Salvador: Editora Juspodivm, 2017

Liszt, Franz von. Tratado de Derecho Penal. 1. ed. Florida: Valletta Ediciones, 2007.

QUEIROZ, Paulo. Direito processual penal: por um sistema integrado de direito, processo e execução penal. Salvador: Editora Juspodivm, 2018.

SALVADOR NET'TO, Almiro Velludo. Plea bargaining e seus contornos jurídicos: desafios estrangeiros para o Brasil. Revista Brasileira de Ciência Criminais, vol. 155/2019, p. 229-264, maio/2019.

SUPREMO TRIBUNAL FEDERAL. Ação Declaratória de Constitucionalidade n. 12 - Distrito Federal. Relator: Ministro Carlos Britto. DJe n. 237/2019. Divulgação 17/12/2019. Publicação 18/12/2019.

$$
\text { . HC } 129346 \text { / ES - ESPÍRITO }
$$

SANTO. Relator: Ministro Dias Toffoli. Julgamento: 05/04/2016. Órgão Julgador: Segunda Turma. DJe-094. Divulgação 10/05/2016. Publicação: $11 / 05 / 2016$.

TÁVORA, Nestor et ALENCAR, Rosmar Rodrigues. Curso de Direito Processual Penal. 7. ed. Salvador: Editora Juspodivm, 2012.

TRIBUNAL REGIONAL FEDERAL DA 5.a REGIÃO. MANDADO DE SEGURANÇA 0804975-89.2019.4.05.00. Relator: Desembargador Federal Paulo Roberto de Oliveira Lima. Julgamento: 20/08/2019. Órgão Julgador: Segunda Turma. 